Marianna Ciemała ${ }^{1}$

Uniwersytet Papieski Jana Pawła II w Krakowie

\title{
Rola słowa Bożego w modlitwie osobistej i liturgicznej wspólnot cenobickich według Reguły Pachomiusza i Asketikonu Bazylego Wielkiego
}

Życie cenobickie, kolejna po anachoretyzmie forma życia monastycznego, zaczęło rozwijać się w Kościele od drugiej połowy IV wieku². Teksty źródłowe dla wczesnego cenobityzmu autorstwa Pachomiusza i Bazylego Wielkiego wskazują, iż codzienny kontakt z Pismem (czy to poprzez modlitwę, przez poznanie reguły, czy przez katechezę biblijną) stanowił fundament monastycznej koinônii ${ }^{3}$. W artykule chcę ukazać na podstawie

1 S. Marianna Ciemała - członkini Stowarzyszenia Życia Apostolskiego „Koinonia św. Pawła” w Kielcach. Ukończyła magisterskie studia pedagogiczne na Akademii Świętokrzyskiej w Kielcach, a następnie uzupełniające magisterskie studia teologiczne na Uniwersytecie Papieskim Jana Pawła II w Krakowie. Kontynuuje studia teologiczne (doktoranckie) z zakresu patrologii. Zainteresowania naukowe: monastycyzm okresu patrystycznego, teologia biblijna. E-mail: r.missio@complex.com.pl.

2 Por. A. Veilleux, La liturgie dans le cénobitisme pachômien au quatrième siècle, Rome 1968, s. 262-264 (Studia Anselmiana, 57).

3 Jeśli chodzi o znaczenie greckiego terminu koinônia w monastycyzmie, można wyróżnić kilka jego charakterystycznych zakresów semantycznych - koinônia jako: realizacja powołania cenobitycznego, wspólnota miłości, wspólnota dóbr, Kościół - zob. m.in. H. Bacht, 
analizy teologicznej tekstów normatywnych pierwszych wspólnot cenobickich najistotniejsze formy obecności słowa Bożego (tj. lektura liturgiczna, medytacja indywidualna, uczenie się na pamięć tekstu biblijnego itd.) w modlitwie wspólnot pachomiańskich i bazyliańskich oraz ich rolę w formacji mnichów i w rozwoju koinônii. W literaturze przedmiotowej niewiele jest opracowań poświęconych wskazanej tematyce ${ }^{4}$, dlatego mam nadzieję, iż niniejszy artykuł będzie stanowił przydatny przyczynek do systematyzacji poruszanej tematyki.

\section{Formacja do modlitwy}

Jak zauważył Adalbert de Vogüé, wspólnota monastyczna kontynuowała wśród mnichów nauczanie rozpoczęte przez Kościół, wprowadzając ich w praktykę modlitwy osobistej i wspólnotowej. Na mocy ewangelicznych i apostolskich rad (Łk 18, 1; 1 Tes 5, 17) celem takiej formacji była praktyka modlitwy nieustannej ${ }^{5}$. Różnorakie formy kontaktu mnicha ze słowem Bożym, takie jak: zapamiętywanie słów Pisma, powtarzanie ich półgłosem, rozmyślanie, medytacja, oficjum, wypływały z przekonania, że słowo Boże jest zawsze żywe i skuteczne, że ma moc przemiany ludzkich serc, oraz z przekonania o jego niezastąpionej roli w umacnianiu więzi z Bogiem, w podążaniu drogą zbawienia i w kształtowaniu wspól-

Koinônia [IV. Dans le monachisme], w: Dictionnaire de spiritualité ascétique et mystique. Doctrine et histoire, t. 8, Paris 1974, s. 1755-1757; L. T. Lefort, Euvres de s. Pachôme et de ses disciples, Louvain 1956 (Corpus Scriptorum Christianorum Orientalium, 159); R. G. Coquin, Un complément aux vies sahidiques de Pachôme: Le manuscrit IFAO, Copte 3, „Bulletin de l'Institut Français d'Archéologie Orientale" 79 (1979); A. Veilleux, La liturgie dans le cénobitisme pachômien..., dz. cyt.; Pachomiana Latina, przekł. A. Bober, W. Miliszkiewicz, M. Starowieyski, Kraków 1996 (Źródła Monastyczne, 11); Pisma ascetyczne, t. 2: Bazyli Wielki, Reguły dłuższe, Reguły krótsze, przekł. i oprac. J. Naumowicz, Kraków 2011 (Źródła Monastyczne, 6).

4 Jeśli chodzi o wspólnoty pachomiańskie - zob. A. Veilleux, La liturgie dans le cénobitisme pachômien..., dz.cyt. W jednym z rozdziałów autor podnosi kwestię obecności Pisma Świętego we wspólnocie pachomiańskiej, ale nie koncentruje się tylko na modlitwie, której zagadnienie podejmuje w następnym rozdziale. Zob. także V. Desprez, Cenobityzm pachomiański, w: Pachomiana Latina, dz. cyt., s. 61-82.

5 Por. A. de Vogüé, Regards surle monachisme des premiers siècles, Rome 2000, s. 16 (Studia Anselmiana, 130). 
noty zgodnej z wolą Boga. Już u początków formacji kandydatów, jeszcze przed powstaniem reguły, Pachomiusz podkreślał doniosłość codziennego kontaktu cenobity ze słowem Bożym. Twierdził, iż należy rozważać (tzn. nauczyć się ich i je odmawiać) psalmy oraz nauki płynące z ksiąg Pisma Świętego, szczególnie z Ewangelii, taki jest bowiem cel powołania ${ }^{6}$. Osoba pragnąca wejść do pachomiańskiej koinônii, pozostając przez kilka dni przed furtą, miała być odpowiednio przygotowana, by mogła być dołączona do grona braci. Co ciekawe, pierwsza czynność, na jaką wskazuje Przykazanie 49 Reguły Pachomiusza, dotyczy właśnie nauki modlitwy: „Zostanie wtedy nauczony Modlitwy Pańskiej i tylu psalmów, ilu zdoła się nauczyć"7. Oto inny fragment Reguły, dotyczący prawdopodobnie dalszej formacji młodego mnicha, który został już wcielony do wspólnoty:

Nowicjusz, który przychodzi do klasztoru, najpierw zostanie pouczony, co ma zachowywać. Gdy on po pouczeniu zgodzi się na to wszystko, zostanie mu zadane do nauczenia się dwadzieścia psalmów albo dwa listy apostolskie, albo jakaś inna część Pisma Świętego ${ }^{8}$.

O doniosłości pamięciowego uczenia się fragmentów Pisma dla formacji cenobickiej świadczy dalszy ciąg tego przykazania, odnoszący się do braci nieumiejących czytać, zakończony stwierdzeniem: „a gdyby nie chciał się uczyć, należy go nawet przymusić do [nauki] czytania". Każdy zatem mnich zamieszkały w klasztorze musiał posiąść tę sztukę i znać na pamięć chociaż część Pisma Świętego - przynajmniej Nowy Testament i Psałterz ${ }^{10}$. Palladiusz, opisując zajęcia mnichów pachomiańskich, zaświad-

6 Por. V. Desprez, Cenobityzm pachomiański, dz.cyt., s. 27. Autor przytacza tutaj także krótki fragment wspólnej wersji żywotu bohairskiego i niektórych żywotów saidzkich: Pachomiusz stopniowo „ustanowił dla nich reguły i tryb życia nie rzucający kłód pod nogi, jak również tradycje pożyteczne dla ich dusz, oparte na Piśmie Świętym”.

7 Pachomiusz, Przykazanie 49, w: Pachomiana Latina, dz.cyt., s. 137.

8 Pachomius Tabennenis, Praecepta 139: „Qui rudis monasterium fuerit ingressus, docebitur prius quae debeat obseruare, et cum doctus ad uniwersa consenserit, da bunt ei uiginti psalmos uel duas epistulas apostoli, aut alterius scripturae partem": Pachomiana Latina, edycja krytyczna A. Boon, Louvain 1932, s. 49-50; przekł. pol.: Pachomiana Latina, dz. cyt., s. 154.

9 Pachomiusz, Przykazanie 139, w: Pachomiana Latina, dz. cyt., s. 154.

10 Por. Pachomiusz, Przykazanie 140, w: Pachomiana Latina, dz. cyt., s. 154. 
cza: „Uczą się na pamięć całego Pisma Świętego"11. Praktyka uczenia się na pamięć dużych partii tekstu Pisma Świętego służyła temu, by opanowanym pamięciowo tekstem modlić się na zgromadzeniu, nieustannie nad nim medytować i żyć zgodnie z nim².

Bazyli Wielki uważał, że nowo wstępujących do wspólnoty należy od samego początku uczyć tego, co mówi Pismo, aby mogli pogłębiać swoją więź z Bogiem. Nauka psalmów przewidziana była jako podstawowy element formacji nowicjuszy:

Jest bowiem czymś stosownym i koniecznym, aby każdy przysposobił sobie $\mathrm{z}$ natchnionego Pisma to, co jest dlań pożyteczne w pogłębianiu swej pobożności, i nie ulegał świeckim naukom ${ }^{13}$.

W przypadku niektórych osób, uznanych za godne, autor Asketikonu mówi o łasce „nauczenia się czterech Ewangelii” ${ }^{14}$. Przykład ten jest swoistym świadectwem kształtowania wśród braci postawy pełnej szacunku i pokory wobec słowa Bożego. Bazyli, stawiając wszystkim braciom wymaganie pamięciowego opanowania psalmów, surowo oceniał postawę tych, którzy ani nie mogli pracować, ani nie chcieli uczyć się tekstów Pisma na pamięć:

Ponieważ Pan powiedział w przypowieści o nieurodzajnym drzewie figowym: „Wytnij je: po co jeszcze ziemię wyjaławia?”, należy takiego otoczyć wszelaką troską, jeśli nie opamięta się, trzeba zastosować także wobec niego to, co nakazano

11 Palladiusz, Pachomiusz i mnisi z Tabennesis, w: Pachomiana Latina, dz. cyt., s. 106.

12 Por. D. Kasprzak, The monastic exegesis and the biblical typology of monasticism in the patristic period, „Theological Research” 1 (2013), s. 89; Pachomiusz, Przykazanie 13, w: Pachomiana Latina, dz.cyt., s. 131: „... wszyscy wedle porządku, w jakim stoją lub siedzą, mają powtarzać to, czego im nakazano nauczyć się na pamięć”; Horsiesi, Księga 51, w: Pachomiana Latina, dz. cyt., s. 265: „Miejmy troskę o czytanie i nauczenie się Pism, i nieustannie oddawajmy się ich rozważaniu [...] To są te słowa, które nas prowadzą do życia wiecznego. Przekazał je nam nasz ojciec i nakazał je nieustannie medytować".

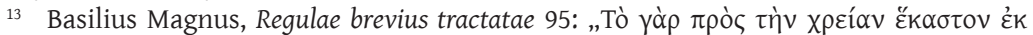

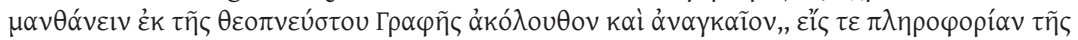

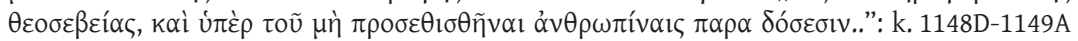
(Patrologia Greaca, 31); przekł. pol.: Bazyli Wielki, Reguły krótsze, w: Pisma ascetyczne, t. 2, dz. cyt., s. 316; V. Desprez, Początki monastycyzmu t. 2, przekł. J. Dembska, Kraków 1999 (Źródła Monastyczne, 2), s. 72.

14 Por. Bazyli Wielki, Reguły krótsze 236, dz. cyt., s. 421. 
czynić z tym, który trwa w grzechu. Kto bowiem nie czyni nic dobrego, zostanie osądzony $z$ diabłem $i$ jego aniołami ${ }^{15}$.

Na uwagę zasługuje fakt, że niechęć do nauki słów Pisma została wyraźnie zestawiona z grzechem. Wynikałoby to z podstawowego założenia biskupa Cezarei, że słowo Boże zawarte w Biblii stanowi jedyną normę życia ascetycznego ${ }^{16}$. Powyższe wskazania stają się jeszcze bardziej zrozumiałe w świetle opisu praktyk modlitewnych monastycznej koinônii.

\section{Modlitwa na zgromadzeniach liturgicznych}

W monasterach pachomiańskich każdego dnia miały miejsce dwa zgromadzenia modlitewne: rano zbierali się razem wszyscy mnisi w kościele („kolekta”, czyli „zebranie” - kopt. soouh, gr. synaxis, łac. collecta), wieczorem w każdym domu bracia gromadzili się na oficjum sześciu modlitw ${ }^{17}$. To ostatnie, dosłownie oficjum „sześciu razy” lub „sześciokrotnej modlitwy", oznacza, jak się wydaje, jedną lub wiele grup modlitw złożonych z sześciu ustępów Pisma, które czytała jedna osoba. Z kolei Szenute twierdzi, że oficjum składało się z wielu recytacji sześciu fragmentów. Każde oficjum (poranne i wieczorne) składało się z powtarzających się części: recytacji psalmów, które odgrywały wiodącą rolę $e^{18}$ modlitwy - czyta-

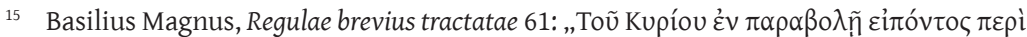

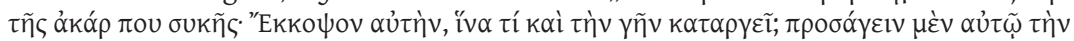

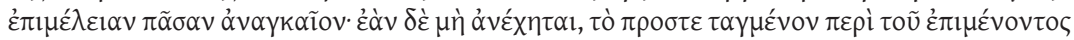

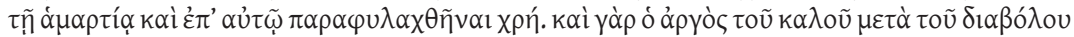

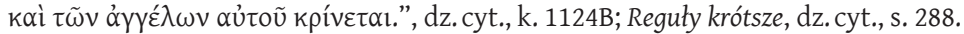

16 Asketikon jest tego przykładem. W zdecydowanej bowiem większości odpowiedzi Bazyli Wielki odwołuje się do słów Pisma.

17 V. Desprez, Cenobityzm pachomiański, dz. cyt., s. 62-63 zauważa, że Prolog do Przykazań i Praw, który jest znany tylko w przekładzie Hieronima, mówi o „sześciu modlitwach wieczorem i o zgromadzeniu modlitewnym sześciu modlitw w poszczególnych domach”. Wskazywałoby to na dwa oficja wieczorne złożone z grup sześciu modlitw: jedno odbywałoby się w kościele, drugie w każdym domu. Aluzję do tego mogą zawierać także inne teksty.

18 Por. A. de Vogüé, Regards sur le monachisme..., dz. cyt., s. 286-287; D. Kasprzak, The monastic exegesis..., dz. cyt., s. 89, zauważa, że również według Reguły św. Benedykta z Nursji Biblia (w szczególności psalmy) budowała główną część oficjum. Psalmy na poszczególne części oficjum zostały ściśle określone przez Benedykta (w oparciu o model rzymski,jednakże ze znacz- 
nia z Biblii. Modlitwie wspólnotowej towarzyszyła praca, którą podejmowali zdrowi, a którą było wyplatanie sitowia. Wynika stąd, jak ważne, również z tego powodu, było wyuczenie się tekstów biblijnych na pamięć. Liturgia eucharystyczna sprawowana w niedzielę połączona była z porannym zgromadzeniem modlitewnym. Tego dnia psalmy odmawiane były w sposób responsoryjny: dyżurni tygodniowi odpowiadali przełożonemu domu albo jednemu ze starszych. Jednym z elementów oficjum była także modlitwa cicha, w czasie której mnisi recytowali wewnętrznie fragmenty Pisma Świętego wyuczone na pamięć $c^{19}$.

Przykazania Reguły mówiące o zgromadzeniach modlitewnych ${ }^{20}$, które zawierają głównie pouczenia dotyczące zachowywania dyscypliny, wskazują na to, z jaką starannością troszczono się o obecność wszystkich cenobitów i ich właściwe uczestnictwo w modlitwie wspólnej. Można wnioskować, że wierność tym przykazaniom oraz zaangażowanie w modlitwę zgromadzenia zgodnie z duchem pachomiańskim przyczyniały się do umacniania jedności we wspólnocie. Według Reguły Pachomiusza sprawowanie sześciu modlitw wieczornych miało być największą radością, a nie ciężarem, który rodziłby się ze znudzenia ${ }^{21}$.

W przypadku wspólnot ascetycznych kierowanych przez biskupa Cezarei modlitwa liturgiczna, skupiona wokół słowa Bożego, była jednym z filarów ich życia wspólnego. Bazyli Wielki wypracował zasady psalmodii dla swoich wspólnot ${ }^{22}$. Choć członkowie wspólnot wezwani byli do

nymi modyfikacjami). Zob. Reguła św. Benedykta 8-18, w: Reguła Mistrza. Reguła św. Benedykta, przekł. T. M. Dąbek, B. Turowicz, Kraków 2006, s. 418-433 (Źródła Monastyczne, 40).

19 Por. E. Wipszycka, Wprowadzenie, w: Pachomiana Graeca, przekł. E. Dąbrowska, Kraków 2013, s. 59 (Źródła Monastyczne, 65); V. Desprez, Cenobityzm pachomiański, dz. cyt., s. 61-62.

20 Zob. Pachomiusz, Przykazanie 6, w: Pachomiana Latina, dz. cyt., s. 129; Przykazanie 8-11 w: Pachomiana Latina, dz. cyt., s. 130; Przykazanie 13-14, w: Pachomiana Latina, dz.cyt., s. 131; Przykazanie 16-18, w: Pachomiana Latina, dz. cyt., s. 132; Przykazanie 121, w: Pachomiana Latina, dz. cyt., s. 151; Przykazanie 141, 142, w: Pachomiana Latina, dz.cyt., s. 154.

21 Por. Pachomiusz, Przykazania i Prawa 10, w: Pachomiana Latina, dz.cyt., s. 171: „Największą radościąjest sprawowanie sześciu modlitw wieczornych wedle wzoru większego zgromadzenia modlitewnego, na które gromadzą się równocześnie wszyscy bracia; jest to tak łatwe, że nikt nie odczuwa ciężaru, który rodzi się ze znudzenia".

22 Por. J. Naumowicz, Wstęp, w: Pisma ascetyczne, t. 2, dz.cyt., s. 30. V. Desprez, Początki monastycyzmu, dz.cyt., s. 72, podkreśla jednak, że psalmodia we wspólnotach bazyliańskich nie ogranicza się jedynie do oficjum chóralnego, o czym mowa będzie dalej. 
nieustannego składania dziękczynienia Bogu - o każdej porze dnia, także w czasie pracy, by dzieło ich rąk Jemu się podobało ${ }^{23}$, potrzebne były stałe godziny na modlitwę wspólnotową: wschód słońca, tercja, seksta i nona, zachód słońca, północ. Każda z nich miała przypominać w sposób szczególny o wyświadczonych przez Boga dobrodziejstwach. Zachęty zakonodawców, by mnisi właściwie przeżywali wspólne modlitwy, miały swe źródło tekstualne w tekstach biblijnych ${ }^{24}$.

Celem jutrzni było poświęcenie Bogu pierwszych poruszeń umysłu i serca, rozradowanie się myślą o Nim przed podjęciem obowiązków wspólnotowych (por. Ps 5, 3; Ps 77, 4). Godzina trzecia dla zgromadzonych braci była sposobnością do tego, by wzorem apostołów napełnionych Duchem Świętym w dniu Pięćdziesiątnicy jednomyślnie składać Bogu hołd i stać się godnymi uświęcenia. W czasie tercji bracia prosili także Boga, by „był dla nich przewodnikiem i nauczycielem dobra” (por. Ps 51, 12-14; Ps 143, 10). O godzinie szóstej, według zaleceń biskupa Cezarei, wspólnota zobowiązana była odmówić psalm dziewięćdziesiąty, aby wszyscy zostali uwolnieni od napaści złego ducha (por. Ps 54, 18). Wzorując się na życiu pierwotnego Kościoła (zob. Dz 3, 1), Bazyli zachęcał do modlitwy wspólnej także o godzinie dziewiątej. Celem modlitwy na zakończenie dnia było dziękczynienie za otrzymane dary i za uczynione dzięki pomocy Boga dobro, wyznanie swych zaniedbań, przebłaganie Boga (por. Ps 4, 5), a gdy zapadała już noc, prośba o spokojny spoczynek. Ponieważ słowa Pisma mówią także o modlitwie o północy (por. Dz 16, 25; Ps 119, 62), również Bazyli wzywał braci, aby usposabiali swego ducha do wysławiania Boga o tej godzinie ${ }^{25}$.

Podsumowując wskazówki odnoszące się do modlitw o różnych porach dnia i nocy, Bazyli wzywał, by żaden z cenobitów nie zaniedbywał któregokolwiek z oficjów ustalonych przez Reguły. Ponadto zwracał uwagę na „zróżnicowanie i odmienność” w wypowiadanych modlitwach czy też

23 Por. Bazyli Wielki, Reguły dłuższe 37.2, w: Pisma ascetyczne, t. 2, dz. cyt., s. 165.

24 Por. Bazyli Wielki, Reguły dłuższe 37, dz. cyt., s. 166-169; V. Desprez, Początki monastycyzmu, dz. cyt., s. 71.

25 Por. Bazyli Wielki, Reguły dłuższe 37, dz. cyt., s. 166-169. 
śpiewanych psalmach oraz na porządek każdej liturgicznej godziny, które odnawiają żarliwość i rozbudzają uwagę ${ }^{26}$.

Wspólna modlitwa psalmami o ściśle określonych porach dnia i nocy, godnie przeżyta, harmonizowała więc całe życie wspólnoty i miała przynieść konkretne owoce w życiu braci: poświęcenie Bogu całej swojej osoby; podejmowanie codziennych obowiązków z sercem przepełnionym Bożą obecnością i myślą skupioną na Nim; uświęcenie; życie poddane panowaniu Boga jako przewodnika i nauczyciela dobra; uwolnienie od zła; życie w prawdzie i przejrzystości; pojednanie z Bogiem i braćmi; wdzięczne usposobienie. Takie było założenie twórcy cenobium i jego kontynuatorów wyrażone w prawodawstwie, choć praktyczna jego realizacja z pewnością nie była wolna od trudów.

\section{Modlitwa nieustanna}

Praktyka modlitwy o określonych porach była wyrazem pragnienia, by zrealizować wezwanie nowotestamentowe: „Nieustannie się módlcie” (Łk 18, 1; Łk 21, 36; 1 Tes 5, 17; Ef 6, 18; Flp 4, 6). Modlitwa liturgiczna była więc drogą do modlitwy nieustannej. Błędem zatem byłoby stawianie wyraźnej granicy pomiędzy modlitwą liturgiczną a modlitwą nieustanną praktykowaną we wczesnym monastycyzmie wspólnotowym, gdyż były one ze sobą ściśle związane ${ }^{27}$.

Mówiąc o modlitwie nieustannej u początków życia monastycznego, trzeba wskazać na praktykę medytacji (gr. melevth, łac. meditari, meditatio), która znana była wcześniej w niektórych szkołach filozoficznych,

26 Bazyli Wielki, Reguły dłuższe 37, dz.cyt., s. 169: „Ci, którzy zdecydowali się czuwać gorliwie na chwałę Boga i Chrystusa, nie powinni zaniedbać żadnej z tych pór. Sądzę, że jest pożyteczne w wyznaczonych porach uwzględniać zróżnicowanie i odmienność w modlitwach i w śpiewie psalmów, a to dlatego, że przez jednostajność dusza staje się oziębła i poddaje się rozproszeniu, natomiast przy wprowadzaniu zmian i zróżnicowaniu psalmodii oraz porządku każdej liturgicznej godziny odnaleziona zostaje na nowo żarliwość i rozbudza się uwaga". Por. E. Amand de Mendieta, Le système cénobitique basilien comparé au système cénobitique pachômien, „Revue de l'Histoire des Religions” 152/1 (1957), s. 52.

27 Por. M. Schneider, Ze źródeł pustyni. Znaczenie Ojców Pustyni dla wspótczesnej duchowości, tłum. E. Krukowska, Kraków 1994, s. 34. 
lecz pierwsi mnisi chrześcijańscy zapożyczyli ją bardziej z tradycji judeochrześcijańskiej ${ }^{28}$. Jej centrum stanowiło słowo Boże, które dla naśladowcy Chrystusa było pokarmem życiodajnym. We wczesnej tradycji monastycznej medytacja polegała na mówieniu (głośno lub półgłosem) z pamięci słów Pisma lub na czytaniu fragmentów biblijnych z kodeksów ${ }^{29}$ i na zgłębianiu ich wewnętrznej treści. W praktyce tej chodziło o zaczerpnięcie z powtarzanego tekstu dla siebie, przyrównane do spożywania posiłku mnich karmił się słowem Bożym. Słowa Biblii recytowane były podczas pracy, jak również podczas wielu innych czynności w ciągu dnia. Stąd tak ważna była praktyka uczenia się całych tekstów Pisma na pamięć, stanowiąca fundamentalny element monastycznej medytacji30.

Prawodawstwo pachomiańskie zawiera kilka wskazań dotyczących modlitwy nieustannej cenobitów. Mnich, poza czynnym uczestnictwem w modlitwie wspólnotowej, zobowiązany był do odmawiania fragmentów Pisma w trakcie różnych czynności: kiedy wychodził z celi, udając się na zgromadzenia ${ }^{31}$; wracając do celi lub udając się na posiłek po zakończeniu zgromadzenia modlitewnego ${ }^{32}$; pełniąc posługę zwoływania braci na posiłek (uderzanie w gong) ${ }^{33}$; rozdzielając braciom słodycze ${ }^{34}$; w drodze

28 Por. D. Kasprzak, The monastic exegesis..., dz. cyt., s. 91.

29 Mnisi pachomiańscy na prośbę wyrażoną wobec dyżurnych tygodniowych otrzymywali kodeks z tekstami liturgicznymi do czytania - zob. Pachomiusz, Przykazanie 25, w: Pachomiana Latina, dz.cyt., s. 133.

30 Więcej na temat medytacji wczesnochrześcijańskiej zob.: E. von Severus, A. Solignac, Méditation [I. Del'Ecriture aux auteursmédiévaux], w Dictionnaire de spiritualité ascétique et mystique. Doctrine et histoire, t. 10, Paris 1980, s. 908-909; M. Schneider, Ze źródeł pustyni..., dz. cyt., s. 38; D. Kasprzak, The monastic exegesis..., dz. cyt., s. 89-91; B. Częsz, Słowo Boże jako pokarm duchowy w nauczaniu Ojców Kościoła, „Teologia Patrystyczna” 6 (2009), s. 10. Zob. także - Horsiesi, Księga 33, w: Pachomiana Latina, dz.cyt., s. 246, który w kontekście wezwania do nawrócenia przekonuje braci jemu powierzonych: „Codziennie zachęca nas [Pan], abyśmy Mu poświęcili czas i poznawali Go". Choć medytację w monastycyzmie określa się jako formę czy element modlitwy, należy podkreślić, że w rozumieniu ojców greckich medytacja jest praktyką duchową odrębną od modlitwy - zob. B. Częsz, Słowo Boże jako pokarm duchowy..., dz. cyt., s. 17.

Zob. Pachomiusz, Przykazanie 3, w: Pachomiana Latina, dz.cyt., s. 129.

Zob. Pachomiusz, Przykazanie 28, w: Pachomiana Latina, dz. cyt., s. 134.

Zob. Pachomiusz, Przykazanie 36, w: Pachomiana Latina, dz. cyt., s. 135.

Zob. Pachomiusz, Przykazanie 37, w: Pachomiana Latina, dz. cyt., s. 135. 
do pracy $^{35}$ i w pracy $^{36}$. Poza tym mnisi pachomiańscy zachęcani byli do modlitwy prywatnej także nocą ${ }^{37}$. Co się zaś tyczy niedzieli, według świadectwa św. Hieronima bracia oddawali się tylko modlitwie i czytaniu, co właściwie stale czynili po skończonej pracy ${ }^{38}$.

Troskę o medytację słów Pisma Pachomiusz zaszczepił w tych, których uformował na swoich następców ${ }^{39}$. Przykładem może być Horsiesi, który w następujący sposób zachęcał braci do nieustannego rozważania słowa Bożego:

\begin{abstract}
Miejmy troskę o czytanie i nauczenie się Pism, i nieustannie oddawajmy się ich rozważaniu, pomnąc na to, co napisane: „Z owocu ust swoich człowiek będzie nasycony i będzie im oddana zapłata za trudy". To są te słowa, które nas prowadzą do życia wiecznego. Przekazał je nam nasz Ojciec i nakazał je nieustannie medytować, aby się wypełniło w nas to, co jest napisane: „Będą te słowa, które Ja tobie dziś przykazuję, w sercu twoim i w duszy twojej. Nauczysz ich twoich synów; będziesz o nich mówił, będąc w domu i chodząc drogą, i kładąc się spać, i wstając. Zapiszeszje jako znak na ręce twojej, i będą nieustannie przed oczyma twoimi. Napiszesz je także na odrzwiach twoich domów, i na progach, abyście się nauczyli bać Pana przez wszystkie dni życia”. Salomon, wskazując na to samo, mówi: „Wypisz je przez szerokość serca twego" ${ }^{40}$.
\end{abstract}

35 Zob. Pachomiusz, Przykazanie 59, w: Pachomiana Latina, dz. cyt., s. 141.

36 Zob. Pachomiusz, Przykazanie 60, w: Pachomiana Latina, dz. cyt., s. 141, Przykazanie 116, w: Pachomiana Latina, dz. cyt., s. 150.

37 Por. E. Wipszycka, Wprowadzenie, dz. cyt., s. 59.

38 Por. Hieronim, List 22.35, w: Pachomiana Latina, dz.cyt., s. 109.

39 Żywot grecki świętego Pachomiusza 89, w: Pachomiana Graeca, dz.cyt., s. 190: „Gdy Pachomiusz przekazał braciom reguły potrzebne dla założenia wspólnoty, zdarzyło się kiedyś w Tabennese, w piekarni, że pewni bracia zagniatając ciasto i pracując, rozmawiali w czasie, gdy nie wolno było rozmawiać, ale według jego pożytecznego przykazania winno się recytować głośno urywki Pisma Świętego. Chociaż Pachomiusz był w tym czasie daleko, w duchu poczuł, że przekroczyli jego przykazanie. Zawołał więc Teodora, gdyż to on był w tym czasie ojcem tego klasztoru, i powiedział do niego: „Idź w dogodnym czasie, zbadaj i zobacz, czy ktoś wczoraj wieczorem w piekarni nie rozmawiał wbrew przykazaniu”. Gdy rozpytywał, znalazł wielu takich i oznajmił mu o tym. Abba Pachomiusz rzekł do niego: „Oni sądzą, że to pochodzi od człowieka. Chociażby jednak przykazanie zostało dane w najmniejszej sprawie, jest wielkie [...]".

40 Horsiesi, Liber 51: „Habemus curam legendarum et discendarum scripturarum, et in earum semper meditatione uersemur: scientes scriptum: Ex fructu oris sui uir saturabitur; et merces laborum eius reddetur. Haec sunt quae nos ducunt ad aeternam uitam, quae nobis tradidit pater noster et iugiter meditanda praecepit; ut compleatus in nobis illud quo scriptum est: Erunt haec uerba, quae ego praecipio tibi hodie, in corde tuo et in anima tua, doce- 
Bazyli Wielki, choć wystrzegał się, by nie popierać (ani nie potępiać) mesaliańskiej idei modlitwy nieustannej, wzywał jednak do ustawicznej modlitwy, którą rozumiał jako „pamięć o Bogu”. W praktyce chodziło o to, by poprzez modlitwę związaną z lekturą Pisma Świętego napełnić duszę aktywną myślą o Bogu. Podkreślał wyraźnie, że medytacja, której celem jest zrozumienie obowiązków chrześcijańskich, powinna opierać się na Bibliii"

We wspólnotach, nad którymi sprawował pieczę, obok wspólnej modlitwy słowem Bożym o określonych porach dnia i nocy ważna była modlitwa praktykowana w różnych okolicznościach, wypowiadana głośno lub w sercu. Według Bazylego:

gdy ręce są zajęte przy pracy, można działać językiem, jeśli to możliwe i stosowne dla zbudowania wierzących, albo przynajmniej sercem - wielbić Boga, jak napisano, przez psalmy, hymny, pieśni pełne ducha. $W$ ten sposób można wypełnić obowiązek modlitwy podczas pracy ${ }^{42}$.

Modlitwa w czasie pracy miała charakter dziękczynny, a zarazem błagalny, co było wyrazem troski o powodzenie i o to, by we wszystkim podo-

bis ea filios tuos, et loqueris in eis sedens in domo, et ambulans in uia, et accubans atque consurgens. Scribes ea pro signo in manu tua, et erunt inmobilia ante oculos tuos. Scribes quoque ea in postibus domuum tuarum, et in liminibus: ut discatis timere Dominum cunctis diebus quibus uiuitis. Salomon quoque idipsum significans dicit: Scribe ea in latitudine cordis tui": Pachomiana Latina, edycja krytyczna, red. A. Boon, dz. cyt., s. 143-144; przekł. pol.: Horsiesi, Księga 51, dz. cyt., s. 265.

${ }_{41}$ Por. J. Naumowicz, Wstęp, dz. cyt., s. 31; Bazyli Wielki, Reguły dłuższe 6.1, dz. cyt., s. 81; P. Szczur, Medytacja słowa Bożego pokarmem dla duszy w ujęciu greckich Ojców Kościoła, „Teologia Patrystyczna" 6 (2009), s. 17. Zob. także - Bazyli Wielki, Reguły dłuższe 6.1, dz.cyt., s. 81: Modlitwa ustawiczna, zdaniem biskupa Cezarei, umożliwiająca zmazanie plam grzechu, wymaga odejścia na miejsce odosobnione.

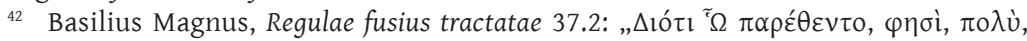

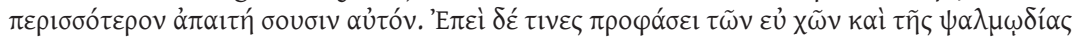

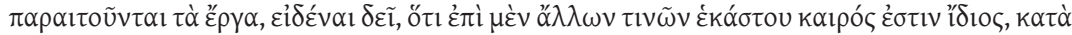

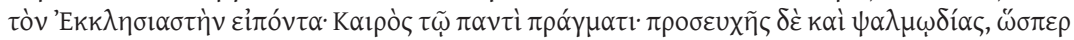

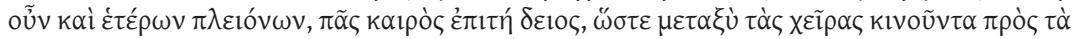

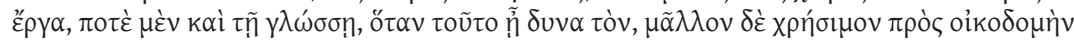

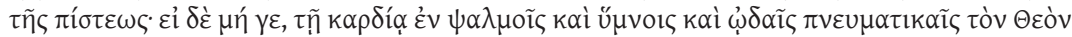

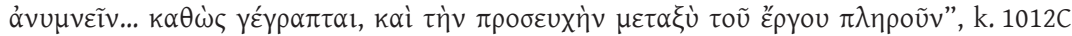
(Patrologia Greaca, 31); Pisma ascetyczne, t. 2, dz. cyt., s. 165. 
bać się Bogu. Zalecenia modlitwy słowem Bożym w Asketikonie odnoszą się także do odbywanych przez braci podróży, podczas których psalmy miały być odmawiane w celu wzajemnego zbudowania ${ }^{43}$. Aby jednak modlitwa psalmami (psalmodia wspólnotowa, a także indywidualna) zaowocowała nieustanną pamięcią o Bogu, wdzięcznym usposobieniem, zrozumieniem i przyjęciem woli Boga zawartej w Jego słowie, by umacniała współbraci i budowała jedność we wspólnocie, należało śpiewać psalmy rozumnie, odpowiednio usposabiając duszę $e^{44}$.

\section{Podsumowanie}

Teksty pierwszych reguł cenobickich wskazują na zakorzenienie norm monastycyzmu wspólnotowego w Biblii. Słowo Boże odgrywało zasadniczą rolę w życiu pierwszych cenobitów: stanowiło praktyczną regułę ich postępowania, a zarazem kształtowało ich duchowość. Mówi się wręcz o Piśmie Świętym jako jedynej regule monastycznej w pierwszych wspólnotach cenobickich. Reasumując, widzimy, że w monasterach pachomiańskich i wspólnotach bazyliańskich w procesie formacji kładziono nacisk na pamięciowe opanowanie słów Pisma. Dla mnichów pachomiańskich minimum stanowiła nauka Nowego Testamentu i Psalmów, dla członków wspólnot biskupa Cezarei była to Księga Psalmów, niektórzy zaś - uznani za godnych - uczyli się czterech ewangelii. Praktyka ta umożliwiała

43 Por. Bazyli Wielki, Reguły dłuższe 39, dz. cyt., s. 171.

${ }_{44}$ Por. Bazyli Wielki, Reguły krótsze 279, dz. cyt., s. 464: „Co znaczy: «Śpiewajcie psalmy rozumnie» (Ps 47, 8 - LXX)? Jak w przypadku pokarmów daje znać o sobie smak wyczuwający jakość każdej potrawy, tak w przypadku słów Pisma Świętego ujawnia się ich zrozumienie. Powiedziano bowiem: «Podniebienie kosztuje pokarmy, rozum zaś rozróżnia słowa» (Hi 12, 11). Jeśli więc ktoś odpowiednio usposabia duszę do zrozumienia sensu każdego słowa, podobnie jak dostosowuje zmysł smaku do jakości każdej potrawy, ten wypełnił nakaz mówiący: «Śpiewajcie psalmy rozumnie»". Zob. także - Bazyli Wielki, Reguły krótsze 238, dz. cyt., s. 422, gdzie biskup Cezarei odpowiada na pytanie dotyczące stosunku do ograniczoności ludzkiego ciała: „Czy jest możliwe, aby nieustannie oddawać się odmawianiu psalmów, czytaniu czy gorliwej rozmowie o słowach Bożych, zupełnie nie czyniąc przerwy, jakiej wymaga zaspokojenie niższych potrzeb ciała? W tej sprawie Apostoł podaje nam zasadę: «Wszystko niech się odbywa godnie i w należytym porządku» (1 Kor 14, 40). Dlatego należy zważać, aby zachować godność i właściwy porządek, stosowny do czasu i miejsca". 
braciom czynne zaangażowanie się w modlitwie wspólnotowej, a recytowanie półgłosem słów Pisma pośród codziennych obowiązków przysposabiało do modlitwy nieustannej, ascezy i walki duchowej. Cenobita praktykujący medytację Biblii był zatem wprowadzany w ściślejszą relację duchową z Bogiem, a recytowanie, powtarzanie, śpiewanie, medytowanie słów Pisma miało przyczyniać się do życia według norm biblijnych. 


\section{Summary}

\section{Rola słowa Bożego w modlitwie osobistej i liturgicznej wspólnot cenobickich według Reguły Pachomiusza i Asketikonu Bazylego Wielkiego}

Teksty źródłowe dla wczesnego cenobityzmu wskazują, iż codzienny kontakt z Pismem stanowił fundament monastycznej koinônii. Artykuł stanowi próbę ukazania najistotniejszych form obecności słowa Bożego w modlitwie wspólnot pachomiańskich i bazyliańskich oraz ich rolę w formacji mnichów i w rozwoju koinônii. Dla analizy teologicznej wybrane zostały teksty normatywne pierwszych wspólnot cenobickich. W Regule Pachomiusza oraz w Asketikonie Bazylego Wielkiego czytamy o wskazaniach dotyczących nauki modlitwy. Ważnym elementem formacji było pamięciowe opanowanie niektórych ksiąg Pisma Świętego. Praktyka ta umożliwiała braciom czynne zaangażowanie się w modlitwie wspólnotowej i przysposabiała do modlitwy nieustannej (medytacji), polegającej na mówieniu (głośno lub półgłosem) z pamięci słów Pisma lub na czytaniu fragmentów biblijnych z kodeksów i na zgłębianiu ich wewnętrznej treści. W ten sposób słowa Pisma zapamiętane, recytowane i rozważane miały być dla cenobitów pierwszą (niektórzy mówią nawet: jedyną) regułą oraz pokarmem duchowym, koniecznym do życia zgodnym z wolą Boga oraz umacniającym jedność wśród braci.

Słowa kluczowe: koinônia, liturgia, medytacja, modlitwa, psalmy, słowo Boże, wspólnota

The Role of the Word of God in the Personal and Liturgical Prayer of Cenobitics Communities's According to the Rule of Pachomius and the Asketikon of Basil the Great

Numerous studies of ancient monastic rules indicate that community monasticism is rooted in the Bible. The Word of God has played an essential role in the life of cenobites: it was constituting a practical rule of their behavior and it was forming their spirituality. Daily contact with the Scriptures through the prayer was a foundation of monastic koinonia, as the source texts evidence. The Article shows the form of the presence of the word of God in the community prayer (of Pachomius and Basil) and their role in the formation of monks as well as in the development of Koinonia. The Rule of Pachomius and the Asketikon of Basil explains the indications of the teaching of prayer. An important element in the formation was the memorizing the books of Scripture. This practice allowed the brothers to involve actively in a community prayer and prepared them to a constant prayer (meditation), consisting of speaking (aloud or quietly) memorized words of Scripture, or reading passages from the Bible codes and exploring their inner content. In this way the memorized, recited and considered words of Scripture were for cenobites first or even the only rule and the 
spiritual food - necessary to live accordingly to the will of God, and strengthening the unity among brothers.

Keywords: koinônia, liturgy, meditation, prayer, psalms, word of God, community

\section{Bibliografia}

Bacht H., Koinônia [IV. Dans le monachisme], w: Dictionnaire de spiritualité ascétique et mystique. Doctrine et histoire, t. 8, Paris 1974, s. 1755-1757.

Basilius Magnus, Regulae brevius tractatae, k. 1052-1306 (Patrologia Greaca, 31); przekł. pol.: Pisma ascetyczne, t. 2: Bazyli Wielki, Reguły dłuższe, Reguły krótsze, przekł. i oprac. J. Naumowicz, Kraków 2011, s. 207-501 (Źródła Monastyczne, 6).

Basilius Magnus, Regulae fusius tractatae, k. 889-1052 (Patrologia Greaca, 31); przekł. pol.: Pisma ascetyczne, t. 2: Bazyli Wielki, Reguły dłuższe, Reguły krótsze, przekł. i oprac. J. Naumowicz, Kraków 2011, s. 45-203 (Źródła Monastyczne, 6).

Coquin R. G., Un complément aux vies sahidiques de Pachôme: Le manuscrit IFAO, Copte 3, „Bulletin de l'Institut Français d'Archéologie Orientale” 79 (1979), s. 209-247.

Częsz B., Słowo Boże jako pokarm duchowy w nauczaniu Ojców Kościoła, „Teologia Patrystyczna" 6 (2009), s. 7-11.

De Mendieta E. A., Le système cénobitique basilien comparé au système cénobitique pachômien, „Revue de l'Histoire des Religions” 152/1 (1957), s. 31-80.

Desprez V., Początki monastycyzmu. t. 2, przekł. J. Dembska, Kraków 1999 (Źródła Monastyczne, 2).

De Vogüé A., Regards sur le monachisme des premiers siècles, Rome 2000 (Studia Anselmiana, 130).

Kasprzak D., The monastic exegesis and the biblical typology of monasticism in the patristic period, „Theological Research” 1 (2014), s. 85-103.

Lefort L. T., Euvres des. Pachôme et de ses disciples, „Corpus Scriptorum Christianorum Orientalium" 159, Louvain 1956.

Pachomiana Graeca, przekł. E. Dąbrowska, Kraków 2013 (Źródła Monastyczne, 65).

Pachomiana Latina, edycja krytyczna: red. A. Boon, Louvain 1932; przekł. pol.: Pachomiana Latina, przekł. zbiorowy, Kraków 1996 (Źródła Monastyczne, 11).

Schneider M., Ze źródeł pustyni. Znaczenie Ojców Pustyni dla współczesnej duchowości, tłum. E. Krukowska, Kraków 1994.

Szczur P., Medytacja słowa Bożego pokarmem dla duszy w ujęciu greckich Ojców Kościoła, „Teologia Patrystyczna” 6 (2009), s. 13-29.

Veilleux A., La liturgie dans le cénobitisme pachômien au quatrième siècle, Rome 1968 (Studia Anselmiana, 57).

Von Severus E., Solignac A., Méditation [I. De l'Ecriture aux auteurs médiévaux], w: Dictionnaire de spiritualité ascétique et mystique. Doctrine et histoire, t. 10, Paris 1980, s. 908-909. 